\title{
Zinc Finger Protein 423
}

National Cancer Institute

\section{Source}

National Cancer Institute. Zinc Finger Protein 423. NCI Thesaurus. Code C104961.

Zinc finger protein $423(1284 \mathrm{aa}, \sim 145 \mathrm{kDa})$ is encoded by the human ZNF423 gene. This protein is involved in differentiation of olfactory receptor neurons. 